\title{
A Post-World War II Tragedy: The Expulsion of the Germans from Poland and Czechoslovakia, 1945-49
}

\author{
By Erica Lamontagne
}

By the end of the Second World War millions of ethnic Germans were living in both Poland and the Sudetenland of Czechoslovakia. A large number of the ethnic Germans who lived in these countries had roots there extending back many generations and truly believed it was their home. There were around nine million Germans living within the pre-war Polish borders. In Upper Silesia, a region in Poland, the German population was largely rural and between 1944 and 1949 about 1.3 million Germans left the area. ${ }^{1}$ By the end of the war and after the Potsdam Conference in 1945, about half of these nine million Germans fled, and many were deported and murdered. ${ }^{2}$ Similar events occurred in the Sudetenland of Czechoslovakia (also referred to as North Bohemia) - between 1945 and 1946 about 1.2 million ethnic Germans were expelled from the region and thousands more killed in labour camps and deportations. ${ }^{3}$ This paper will examine the nature of the expulsions from both Poland and the Sudetenland and the expelled Germans' integration into the Soviet and Western zones of Germany. It will also briefly examine various explanations for these expulsions after World War II. Already a war-torn country trying to recover from the devastating effects of Nazism, Germany now had to incorporate millions of poor, sick, and homeless people into its cities. By examining the expulsion of ethnic Germans from both Poland and Czechoslovakia this essay will show that the cruel, inhumane, and rapid way in which the Germans were expelled had a negative impact on their integration into Germany. It will also show that the expulsion of ethnic Germans negatively affected Poland, Czechoslovakia, and Germany.

The expulsion of ethnic Germans from Poland began immediately after the end of the war. Many Germans were replaced by Poles from other parts of Poland and the Soviet Union. ${ }^{4}$ The nature in which the Germans were expelled, the so-called "wild expulsions,"5 and the later expulsions after the Potsdam conference in 1945 help to explain why ethnic Germans had a difficult time reintegrating into West and East German society. The nature of the expulsion also helps to explain the crisis that followed World War II in Poland. ${ }^{6}$ In the article "Reinterpreting the Expulsion of the Germans from Poland, 1945-49," Hugo Service analyzes a case study of ethnic Germans from the Jelenia Gora District in Lower Silesia after World War II. Service notes that the expulsions began immediately following the end of World War II and were carried out 
by Polish soldiers and militia, not by the government. The cruelty and disorganization of these summer expulsions showed that they were marked by revenge motives. The expulsion of the ethnic Germans in the Jelenia Gora District was facilitated by the movement of Poles to Western Poland from the central and former East-Polish territories. In order to make room for the migrating Poles, soldiers and militiamen removed ethnic Germans from their homes and placed them in old concentration camps and ghetto-like areas. ${ }^{7}$

The expulsion of ethnic Germans by Polish citizens, militia, and soldiers is what historian R.M. Douglas has called the "wild expulsions." In his book, Orderly and Humane: The Expulsion of the Germans after the Second World War, Douglas asserts that although the allied powers stated their support for the expulsions of ethnic Germans from Poland and Czechoslovakia at the end of the war, Czechoslovaks and Poles were wary of trusting the great powers because of pre-war experiences. ${ }^{8}$ In an attempt to take matters into their own hands, what resulted was the "wild expulsions," forced labour, and mass murders of ethnic Germans. To control the "wild expulsions," the Big Three (Britain, the United States, and the Soviet Union) initiated the Potsdam Conference in July and August 1945, which called for the "orderly and humane" transfer of population. At this conference it was decided that Poland's western border would be moved to the Oder-Nieße line giving Poland back the western territory that was lost to Germany during the war. ${ }^{9}$ Poles were also told at the conference that they had to temporarily stop expelling Germans because the Western and Soviet zones of Germany were having a difficult time keeping up with the influx of ethnic German refugees. ${ }^{10}$ As a result, in the autumn of 1946, Polish officials created assembly camps to accommodate expellees for several days before their departure. Expelled Germans often lived in these camps for weeks or months because with millions of Germans being expelled at once, the infrastructure became overwhelmed. This resulted in the Germans often struggling to survive for lack of food, warm clothes, and housing. ${ }^{11}$

After the Potsdam Conference in 1945 when Poles were told to temporarily stop expelling Germans so Germany could better prepare for the influx of refugees, Polish officials in the Jelenia Gora District began to take measures to compel Germans to leave 'voluntarily.' These measures resembled Nazi policy towards Jewish people during the Third Reich and caused ethnic Germans to undergo "collective pauperization." Ethnic Germans were forced to pay higher prices for fuel, food and housing, paid lower wages or no wages at all for work, were not 
allowed to access their savings in German banks, forced to wear white armbands to distinguish themselves as German, and were subjected to forced labour, harassment, violence, and robbery. ${ }^{12}$ It is possible the measures taken against the Germans in the Jelenia Gora District were also applied in other regions of Western Poland with large German populations.

As stated previously, the expulsion of ethnic Germans from Western Poland was facilitated by the migration of Poles from Eastern and Central Poland at the end of the war. Although Poland still faced a crisis as a result of the expulsions, the country was able to recover more quickly because of the replacement of Germans with Poles. In Philip Ther's article, "The Integration of Expellees in Germany and Poland after World War II: A Historical Reassessment," he describes the statistics of Poles returning or migrating to Western Poland at the end of the war. At least 2.1 million Poles from Eastern Europe and eastern Poland who had been deported to Siberia during Soviet occupation had been returned to Poland by 1948. Also, 2.2 million Poles moved from Western Europe back to Poland at the end of the war. Poles moving from the east to replace ethnic Germans being deported were allowed to bring two tonnes of belongings per family and some of their cattle and horses (compared to expelled Germans only being allowed 1 piece of luggage per person). Despite the large amounts of belongings allowed, many things were lost or damaged during the trip. Ther explains that by May 1946, only $30 \%$ of horses and $50 \%$ of cows that were supposed to be transported from Eastern Poland to Silesia arrived there. ${ }^{13}$ This made newly arriving Poles very impoverished many were rural farmers, and they struggled for food, barely surviving let alone thriving in a new region without their cattle.

Another reason why Poland fared somewhat better than Czechoslovakia and Germany after the expulsions was because they kept skilled German labourers back until equally skilled Polish labourers arrived. This helped to prevent the collapse of industry in Poland. Polish authorities also kept back Germans who worked on state farms because the farms relied heavily on German workers and the majority of new Polish settlers did not want to work on them. ${ }^{14}$ Through not expelling ethnic Germans who were vital to the stability and continuation of the Polish economy, Poland fared better in the long run than Czechoslovakia. Poland's Three Year Recovery Plan shows the effects of the expulsion and the replacement of Germans with Poles in the Western territories. By 1950, coal production rose to 80 million tons, over one million peopled entered industries, and about three million Poles had been settled in Western Poland. ${ }^{15}$ 
Despite Poland's quick recovery from the expulsions, the immediate effects were quite negative. At the beginning of the expulsions when German towns were rapidly cleared of their residents, all essential services also were cleared away. These services included a local council, police force, municipal administrators, as well as farmers, factory workers, and business owners. ${ }^{16}$ This no doubt caused chaos and instability in many local economies in Poland immediately following the war and until Poles came to the West as replacements.

The expulsions in Czechoslovakia were far more violent and cruel in nature than the expulsions in Poland and were carried out in a far less organized manner. The disorganization and cruelty of the expulsions in Czechoslovakia sheds light on why the expulsions had such a negative impact on the country's economy in the 1950's and 1960's. The expulsion of ethnic Germans from the Sudetenland was clearly tainted with hatred and motives for revenge against the Germans. At the end of the war, when the rest of Europe was celebrating, members of the Waffen-SS in Czechoslovakia continued to fight and staged vicious counter-attacks against the Czechoslovaks. As a result, when the Germans finally capitulated, Czechoslovaks sought revenge through violence. Many Germans were hanged and lit on fire, and mobs went through hospitals to look for easy German targets to kill. ${ }^{17}$ On 19 June 1945, decree no. 16 was ratified which called for the internment of Sudeten German craftsmen, businessmen, and professionals. Hundreds of thousands of Sudeten Germans were put into labour camps and old Nazi concentration camps where they were held until arrangements were made for their deportation. The majority of inmates in these camps were women and children because many of the men still had not returned from the war. Regulations that exempted the young, the old, pregnant women, and the disabled from being placed in these camps were almost entirely ignored. ${ }^{18}$

The extent of the violence and disregard for ethnic German rights in Czechoslovakia can be seen in two accounts of experiences at the time. One account is by Hubert Schütz, a businessman and former town councillor in the town of Jägerndorf in Czechoslovakia. Published in 1947, Schütz gives an account of his experiences upon returning to Jägerndorf in June 1945 after the fighting had ceased. He stated that when he and other ethnic Germans returned on 4 June 1945 they "immediately sensed the completely changed atmosphere." ${ }^{19}$ Many of their homes were now occupied by Czechs, and Schütz's home specifically was occupied by the Czech food office. After finally gaining access to his home, Schütz and his wife found many of their belongings and furniture damaged or stolen, but regardless of this, he stated that they were 
still happy to be back home. ${ }^{20}$ Despite the destruction of their home and the changed atmosphere in the Sudetenland, it was clear that Schütz still had trust in the Czechoslovaks and truly believed that the Sudetenland was his home. This can be seen when he states, "we were in fear and anxiety, but still, we did not expect the worst because we somehow felt comparatively safe at home and amongst our own people." 21 This phrase "our own people" demonstrates that many ethnic Germans living in the Sudetenland did not view themselves as part of former Nazi Germany, but as citizens of Czechoslovakia. This view contrasts how Czechoslovaks saw ethnic Germans: as collaborators of the former Nazi regime. It is clear the Czechoslovaks blamed ethnic Germans in the Sudetenland for the atrocities the Nazi regime carried out. When Schütz was taken prisoner he was beaten and forced to say in Czech, "we thank our Fuhrer Adolf Hitler, the Chachar, that we are here." Schütz explains that he and other prisoners were marched to an internment camp for Germans where thousands were already being held prisoner. ${ }^{22}$ Within the account that Schütz tells of his experience in the Sudetenland at the end of the war, it is evident that his unjustified removal from his home and the treatment he received from his Czechoslovak neighbours caused much grief and confusion which would have negatively affected his eventual resettlement into Germany.

Another account that shows the extent of the violence and the disregard for ethnic German well-being in the Sudetenland at the end of the war is that of E. Wollmann, who was a government inspector of German descent. He discusses his expulsion from Friedland in June 1945 and states that he was warned to be at the railway station at 2 am to be expelled. Wollmann explains that he "hated the Nazi regime from the very beginning" and did not feel the "slightest bit guilty" 23 for what they had done because he did not see himself as a supporter of the Nazis. Wollmann describes his experience upon arriving at the train station. All people and their possessions were subject to a search and all cash, documents, watches, and things that could be used as a weapon were confiscated. All new or fairly new articles of clothing were also taken away. ${ }^{24}$ Confiscation of valuable goods, documents, and many articles of clothing forced many ethnic Germans to arrive in East or West Germany with virtually nothing to their names, which made their integration increasingly difficult. Wollmann then goes on to describe his arrival on German soil, on the fields of Gorlitz, where hundreds of thousands of expelled Germans spent their first few months as refugees. He describes the hunger that all of the expelled Germans experienced, as well as the rapid spread of diseases such as dysentery and typhus. ${ }^{25}$ These 
accounts display the violence, disorganization, and rapid population loss that Czechoslovakia experienced as a result of the expulsions. In both accounts, it is clear that this was the period of "wild expulsions" that were carried out by militia, soldiers, and citizens that Douglas describes in his book. ${ }^{26}$ Both experiences occurred before the Potsdam Conference in July and August 1945, and both men describe their experiences as being violent and cruel.

The expulsion of ethnic Germans from the Sudetenland had a more negative long-term impact on the economy of Czechoslovakia compared to the effects of the expulsion in Poland. In his article, "Ethnic Cleansing, Communism and Environmental Devastation in Czechoslovakia's Borderland's, 1945-1989," Eagle Glassheim argues that North Bohemia's deterioration and the expulsion of the Sudeten Germans are connected. Immediately following the expulsion of the Germans, Czechoslovakia found itself with a crisis regarding shortages of workers in mining and glass production. ${ }^{27}$ Like the replacement of Germans in Poland by Poles from the East, Germans in the Sudetenland were replaced by migrating Czechs and Slovaks; but unlike the Poles, the resettled Czechs and Slovaks did not come immediately after the Germans were expelled and did not respond as well to their new land and surroundings. Glassheim states that in the 1960's communist officials were complaining about 'the local population's 'indifference' to their surroundings." ${ }^{28}$ This "indifference" was a result of the alienation felt by Czechs and Slovaks who were living in the Sudetenland and since they were unfamiliar with the landscape they neglected the land and surrounding industry. ${ }^{29} \mathrm{~A}$ major difference between Poland and Czechoslovakia regarding the expulsions was that Poland took more organizational measures to ensure their industry and economy would not collapse after the ethnic Germans had left. In the case of Czechoslovakia, it was hatred and violence fuelling the expulsion of the Germans and they took less care in ensuring stability in the aftermath. In the Sudetenland, as was seen in Schütz's account, many Germans felt attached to their homes and cared about their homeland which is what kept stability in the region. When Czechs and Slovaks migrated after the expulsion, they cared little for the land they were moving to and so allowed the region to spiral into chaos. In Germany, on the other hand, measures were taken in an attempt to prevent the chaos that would occur with an influx of German refugees.

The expulsions of ethnic Germans from both Poland and Czechoslovakia had negative impacts on the Western and Soviet zones of Germany. The allied powers initiated the expulsion of the Germans and believed that Germany should bear the costs that came with resettlement. 
An International Population Transfer Commission was established to represent the Big Three, Poland, and Czechoslovakia. This commission had sole authority in determining the timing and circumstances of the expulsion in order to prevent an economic collapse in Germany. The commission knew that Poland and Czechoslovakia would want to speed up the expulsions and this would be detrimental to the German economy. ${ }^{30}$ Between 1944 and 1949 about 4.3 million expellees (24.2\% of the East German population) settled in the Soviet Zone in Germany (the German Democratic Republic after 1949). By 1950, up to eight million expellees (about 17\% of the West German population) came to West Germany. ${ }^{31}$ The "collective pauperization" of ethnic Germans in Poland that Hugo Service describes in his article negatively impacted the integration of ethnic Germans in both the Western and Soviet zones. ${ }^{32}$ One of the major problems that came with the expellees was how to properly settle them. Germany was already facing a housing problem as a result of the bombing in the war, and now they faced the additional burden of supplying millions of meals, beds, and homes to the expellees. Expellees were mainly settled in rural areas because there was more space, however, availability of work for them was not considered. Due to overpopulation, diseases caused by malnutrition and poor sanitary conditions spread rapidly. ${ }^{33}$ In order to get a proper picture of the effects of the expulsion on Germany, the Western zones and Soviet zone must be analyzed separately because they handled the situation very differently.

In the years immediately following the expulsion, the Western zones of Germany dealt with the expellees through a policy of containment. Newly settled German refugees were not allowed to organize themselves into interest and political groups because having organizations for new settlers would "disturb the process of assimilation." "34 This policy created difficulties for the expellees to survive in a market economy. The struggle for survival also came with psychological impacts for the expellees. Many were experiencing homesickness and were working only to secure their immediate needs. ${ }^{35}$ This was a lasting effect of the violence and quick uprooting from their homes the expellees experienced. By 1948, authorities in West Germany realized their containment policy towards expellees was not working and they switched to an active and supportive policy. Acknowledging that the expellees had suffered great losses, new laws were created in West Germany for the care of expellees with the intent to help them carry the burden of their expulsion. ${ }^{36}$ Although West Germany slowly recovered from the influx 
of expellees, the rapid and careless way in which Poland and Czechoslovakia expelled ethnic Germans made it very difficult for authorities to control the situation.

In the Soviet zone of Germany, and later the GDR, authorities did more for expellees up until 1948 than the West German authorities did in West Germany. Soviet authorities issued a redistribution policy in an attempt to integrate the expellees into society and make their lives easier. Apartments and rooms of former Nazis were seized and given to people in need and land was also redistributed. Although the reforms made in East Germany for the benefit of expellees seemed to be going well, by 1948 the policy had reached its limits. Nothing was left to redistribute and redistribution was costing too much money. Farms were also not sustainable because of a lack of livestock and technical equipment. ${ }^{37}$ Despite initial efforts on the part of East German authorities to assist the expellees, in the long-term expellees suffered more than in West Germany. Having run out of solutions to the growing problem, authorities in East Germany began to suppress it. Authorities accused expellees of being responsible for the rise of Nazism, and expression of Silesian or Sudeten culture and identity was forbidden and prosecuted. Expellees had an especially hard time rising to high levels in the Communist party in the GDR and many careers in industry ended at middle levels. ${ }^{38}$ In East Germany it seemed as though expellees were being punished for something they had no control over. The problems they faced upon integration into Germany were a result of their quick expulsion from Poland and Czechoslovakia and their pauperization along the way.

On the whole, the rapid, violent, and disorganized way in which ethnic Germans were expelled from Poland and the Sudetenland of Czechoslovakia impacted Poland and Czechoslovakia after the expulsion. The "wild expulsions" that occurred before the Potsdam conference in the summer of 1945 were carried out by militia and soldiers from both Poland and Czechoslovakia and caused millions of ethnic Germans to flood into Germany. After the expulsions, Poland fared better than Czechoslovakia because of migrations of Poles from Eastern and Central Poland to the west to settle the land that the Germans had previously lived on. The Sudetenland experienced far more economic difficulties because ethnic Germans were not replaced by Czechs and Slovaks immediately following the expulsion and so the economy destabilized as a result of a lack of workers. Even when Czechs and Slovaks had settled in the Sudetenland they did not feel an attachment to it like the previous German residents did and this resulted in a decrease in industrial output and a lack of labour. The expulsion also had a negative 
impact on the expellees' integration into West and East Germany. The violence and pauperization that the expellees underwent before they were deported left them with next to nothing upon their arrival in Germany. Both Western and Eastern German authorities had to face the problem of housing, food, and job shortages with the influx of millions of German refugees. Western Germany had better long-term results because of an active and supportive policy towards expellees. On the other hand, East Germany had poorer long-term results because of the failure of redistribution and a failure to find a new solution to the expellee problem. Further research could be done on this topic to answer why the Poles and Czechoslovaks were so violent and disorganized in expelling ethnic Germans from their countries, and this might open a new perspective regarding the after-effects of the expulsion.

\section{NOTES}

${ }^{1}$ Karl Corell, "Poland's German Minority," in German Minorities in Europe: Ethnic Identity and Cultural Belonging, ed. Stefan Wolff (New York: Berghahn Books, 2000), 75.

2 Ibid., 78.

${ }^{3}$ Eagle Glassheim, "Ethnic Cleansing, Communism, and Environmental Devastation in Czechoslovakia's Borderlands, 1945-1989," The Journal of Modern History 78.1 (March 2006): 65, accessed 17 November 2016, http://www.jstor.org/stable/10.1086/499795.

${ }^{4}$ Philip Ther, "The Integration of Expellees in Germany and Poland After World War II: A Historical Reassessment," Slavic Review 55.4 (Winter 1996): 779-780, accessed 17 November 2016, http://www.jstor.org/stable/2501238.

${ }^{5}$ This will be explained in the next few pages.

${ }^{6}$ Although it should be noted that Poland had recovered from the expulsions and the affects of World War II much quicker than Czechoslovakia and Germany.

${ }^{7}$ Hugo Service, "Reinterpreting the Expulsion of Germans from Poland, 1945-9," Journal of Contemporary History 47.3 (2012): 536-538, accessed 20 November 2016, http://www.jstor.org/stable/23249005.

${ }^{8}$ R.M Douglas, Orderly and Humane: The Expulsion of the Germans after the Second World War (New Haven: Yale University Press, 2012), 93.

${ }^{9}$ Ibid., 78, 93.

${ }^{10}$ Service, "Reinterpreting the Expulsion," 538.

${ }^{11}$ Douglas, Orderly and Humane, 178.

12 Service, "Reinterpreting the Expulsion," 539.

13 Ther, "The Integration of Expellees," 784-787.

${ }^{14}$ Service, "Reinterpreting the Expulsion," 544-545.

${ }^{15}$ Geoffrey North, "Poland's Population and Changing Economy," The Geographical Journal 124.4 (December 1958): 519, accessed 19 November 2016, http://www.jstor.org/stable/1790941.

${ }^{16}$ Douglas, Orderly and Humane, 256.

17 Ibid., 95.

${ }^{18}$ Ibid., 135, 137.

19 "No. 37 Report of experiences (letter) of Hubert Schutz sen., businessman and former town councillor of Jagerndorf," in The Expulsion of the German Population from Czechoslovakia, ed. Theodor Schieder, trans. G.H. de Sausmarez, in vol. IV of Documents on the Expulsion of the Germans from East-Central Europe (Bonn: The Federal Ministry for Expellees, Refugees, and War Victims, 1960. Originally published 4 January 1947), 410.

${ }^{20}$ Ibid., 410. 
${ }^{21}$ Ibid., 411.

${ }^{22}$ Ibid., 411-412.

23 "No. 78 Report of the experiences of E. Wollmann, government inspector, of Friedland (Iser Mountains)," in The Expulsion of the German Population from Czechoslovakia, ed. Theodor Schieder, trans. G.H. de Sausmarez, in vol IV of Documents on the Expulsion of the Germans from East-Central Europe (Bonn: The Federal Ministry for Expellees, Refugees, and War Victims, 1960. Originally published 27 April 1953), 462.

${ }^{24}$ Ibid., 462-463.

${ }^{25}$ Ibid., 463.

${ }^{26}$ Douglas, Orderly and Humane, 93.

${ }^{27}$ Glassheim, "Ethnic Cleansing," 66.

${ }^{28}$ Ibid., 85.

${ }^{29}$ Ibid., 66, 70.

${ }^{30}$ Douglas, Orderly and Humane, 77-78.

${ }^{31}$ Ther, "The Integration of Expellees," 779.

${ }^{32}$ Service, "Reinterpreting the Expulsion," 538.

${ }^{33}$ Ther, "The Integration of Expellees," 788-89.

${ }^{34}$ Ibid., 790.

${ }^{35}$ Ibid., 791.

${ }^{36}$ Ibid., 791.

${ }^{37}$ Ibid., 793-795.

${ }^{38}$ Ibid., 795-96. 